\title{
The Modern Russian-Speaking Communities in the World: Formation, Assimilation and Adaptation in Host Societies
}

\author{
Sergey V. Ryazantsev \\ Institute for Social-Political Research of the Russian Academy of Sciences \\ Email: riazan@mail.ru
}

\section{Doi:10.5901/mjss.2015.v6n3s4p155}

\begin{abstract}
Modern Diasporas are not just historically dispersed peoples, united by common ethno-cultural roots, maintaining real or imaginary ties with their historic homelands. Modern Diasporas should be viewed as strategically vital trans-national networks with remarkable social, political and economic potential. The Russian Diaspora of today has formed in unique historical circumstances, as the consequence of the break-up of the Soviet Union, the formation of new nation-states in its place, and a massive wave of emigration from this area since the early 1990s. This paper will examine the global nature of the contemporary Russian Diaspora, both in the West and in the Far East. Focusing on the example of the USA, Finland, Cyprus, Japan and Korea, it will examine the statistical size of this Diaspora, its ambiguous ethno-cultural composition, its patterns of integration and assimilation, its forms of diasporic self-organization and support, and, finally, the creation of Diaspora-based business, professional, socio-cultural and educational networks. Furthermore, this paper will look at how these diasporic groups represent the Russian Federation abroad and the role that they increasingly play in Russian diplomacy and foreign policy.
\end{abstract}

Keywords: Russian Diaspora, identity, assimilation, modern society, migration.

\section{Introduction}

The notion of Diaspora traditionally originates from the history of the Jewish people, in the context of which it was conceptualized as in many ways a unique phenomenon (Levin, 2001). However, over the centuries, as ethnic-based migration and population dispersal became widespread and very diverse, the term Diaspora started to be applied broadly and loosely to numerous other ethnic groups, whose predicament could be modeled on the Jewish experience of dispersal, even if sometimes only remotely so. In this paper, I am interested in the formation of a new kind of Diaspora, typical of the twenty-first century, a Diaspora that is understood not simply as part of a nation living abroad, having common mental, cultural and historical roots and striving to maintain various types of links with its historic native land, but rather as a vibrant transnational network, which, in the new context of a global economy and twenty-first-century technology, is developing into a trans-national structure with remarkable social, cultural, political and economic potential. At the beginning of 1990s the size of the Russian Diaspora beyond the CIS-states and the Baltic states was about 2 million persons. They lived primarily in the USA (about a half of this Diaspora), in Israel and Germany (300,000 persons respectively), as well as in Latin America (about 150,000) and Canada (around 100,000), with the rest spread elsewhere. This Diaspora had formed through migration both before and after the 1917 revolutions as well as through several more recent migration waves during the Soviet period. The break-up of the Soviet Union and the creation of newly independent states have vastly increased the size of the Russian Diaspora, which expanded further through more active emigration from Russia and the other FSU states over the past fifteen years or so. Currently the size of the Russian Diaspora (Russians living outside the borders of the Russian Federation) exceeded 25 million persons, which, in terms of size, is second only to the Chinese Diaspora. And yet, according to the Russian Ministry of Foreign Affairs, only 1.5 million Russian citizens are registered with the Russian Consulates as permanently residing in a foreign country. This, however, is a considerable underestimate, arguable only $10 \%$ of the overall number of Russian citizens actually living abroad.

\section{Metods and Materials}

The data for this research was collected by employing the following methods: Firstly, the statistical method, which included gathering and processing statistical data regarding human trafficking offences, use of slave labour and human smuggling provided by the Russian Ministry of Interior and the Investigative Committee of the Russian Federation for the years 2009-2012; data from the Russian Federal Migration Service concerning the quantity and structure of permits for 
work in the Russian Federation issued to foreign citizens, and also data concerning the number and breakdown of Russian citizens employed abroad between 2006 and 2012. Secondly, the sociological method, which included 18 interviews with experts, is including government employees, law enforcement officials, embassy representatives, employees of international organizations, employees of non-governmental organizations, managers of companies which provide employment services, trade union leaders, academics, etc. Thirdly the cartographic method, which entailed preparing a number of graphical materials, cartograms and diagrammatic representations relating to human trafficking and irregular migration. Fourthly, the analytical method, which entailed analyzing and reviewing legislation within the Russian Federation, intended to combat human trafficking for forced labour and irregular migration. This thesis focuses on the approaches of Russian political elites and intellectuals towards Russian nation and its diaspora as off 1991; especially on the four ways the Russian nation is nowadays defined: 1) The Russian nation in the context of the Union Identity, 2) The Russians as a nation of Eastern Slavs, 3) The Russians as a community of Russian speakers, 4) The Civic definition of the Russian nation (Rowley, 2000). While Putin declare that they are in favor of the civic definition of a nation within its borders, the policies they pursued concerning the Russians in near abroad have been omitted this sense of community. Thus, this thesis presumes that Russian Diaspora, the twenty-five million people who suddenly found themselves beyond the borders of Russia with the demise of the Soviet Union, is an essential element in defining the new Russian identity. The premise "Russian Diaspora" paved the way for Russian political elites and intellectuals to define Russia as the ethnic homeland for Russians. On the other hand, the Russian population residing in near abroad developed different interpretation of "homeland". Factors such as the years of their settlement in the newly independent post-Soviet states, their role in the economic life, mixed marriages, cultural distance between them and titular nations, the size of their population in the host states, the closeness of their settlement to Russian border or the nature of the nation building process in the newly independent post-Soviet states contributed to the perceptions of homeland amongst Russian populations. Therefore, this thesis examines how Russian political and cultural elites built the Russian nation according to the Russian Diaspora. It further focuses on the self-identification of Russians who lived abroad and considers their relations with the nationalizing regimes of the newly independent post-Soviet states and Russia. The modernist approach considers the nation as an essentially modern phenomenon which emerged at a particular time and space in history. According to the modernist approach, nations are creations of modernity, because their very existence requires an industrial society with a high level of literacy and mass communication. Modernist scholars can be distinguished with those who focus on social-cultural transformation such as Ernest Gellner, Benedict Anderson, Miroslav Hroch and those who focus on political transformation such as Eric Hobsbawm, John Breuilly in industrialization process (Değirmen, 2008). According to modern Western scholars who have made a significant contribution to the development of the theory of nationalism (D Connor, E. Gellner, E. Smith et al.), Ethnicity - this is not a vestige of traditional society and an integral part of contemporary social transformations conducive to the growth of the number of contacts between first of distinct ethnic groups are involved in the competition for the same economic sphere, which are generated by modernization. Such a sharp intensification of interethnic interaction leads to increased ethnic identity and the aggravation of inter-ethnic conflict potential. Conflictologycal aspect of ethno-political studies of contemporary diasporas updated and post-Soviet realities of Russian society. Diaspora becomes a form of self-identity of many groups of old residents of Russia. So, some of the Armenians, Greeks, Koreans, Germans, Poles and other Russian citizens of foreign origin, are united in the national-cultural autonomies and centers, various associations for cultural and ethnic lines. In this regard, it is necessary to study ethno-political factors that contribute to the intensive care unit, "awakening" and mobilize the Diaspora ethnicity. In this regard, particularly relevant to develop integration problems emerging in the process of migration diaspora communities. So today is very important is the problem of the diaspora as ethno-political phenomenon. The problem of self-determination of the diaspora due to the absence or underdevelopment of their political entities implementing ethnic interests, combined with the existence of the nation-state of the same name of the ethnic majority in the territory of their historical homeland; This problem defines conflict "dual identity", "dual loyalty" (Popkov, 2003; Karabulatova \& Karelina, 2006; Karabulatova, 2013 \& Karabulatova, Sayfulina \& Ahmetova, 2013). Some researchers believe that the latter circumstance often makes them "strangers" in the eyes of the state of origin and the state of the settlement. Achieving the goal was carried out at three levels of ethno-political research. At the first level, the dialectic, system, structural-functional, comparative, historical approaches. At the second level, such approaches have been used as political science, sociology, social, psychological, cultural. At the third level, the methods of observation, survey, analysis of documents and statistical data. In the course of the project the author relied on the following logical methods: analysis (in, inter alia, multifactorial (polikauzalny)) and synthesis (eg multiparadigmatic, interdisciplinary). Thus, the dissertation research is based on the integration of elements of the following traditions: general scientific, theoretical, empirical and general logical, allowing, in our opinion, to achieve a deeper and more adequate understanding of the nature of ethno-political phenomenon of modern diasporas identify the social and cultural foundations of their conflict-and 
consensus-building.

\section{Results}

A significant portion of the Russians that have gone abroad belong to that intellectual class which in recent times lived according to the ideas of the West. The author examines the global clusters separately Russian diaspora in the world: the United States, Europe, Asia. The problem of cultural and political recognition of modern diasporas in the context of globalization manifests itself primarily in the transformation of the institution of citizenship in the host societies. Thus there is a contradictory interaction of two trends: "transnationalization" and "differentiation". On the one hand, the institution of citizenship is a factor weakening the perception of other cultures as diaspora groups and promote their integration, on the other hand it is aimed at the preservation of national and cultural identity of the host societies and emphasizes another cultural status diasporas.

The Russian Diaspora in the USA. A large Russian Diaspora is currently settled in the United States of America. Russian language is the seventh most common in the United States (Sensus, 2000; Pronin, 2001; Nitoburg, 2001 \& Nitoburg, 2003). However, the data available on this country must take into account the way in which the USA collects information about the country's ethnic composition. The principal feature of US migration statistics is that labour migrants are granted only non-immigration visas, and are treated as staying in country temporarily, which means that, as a rule, they are not properly accounted for in immigration statistics. The US census does, however, include data useful to the analysis of the country's ethnic composition, and these include place of birth, language use, and ethnic identity itself. According to the 2000 US census, 706,000 persons included in it said that they spoke Russian. Approximately 2.6 million of American citizens, or one percent of country's population, declared themselves ethnically Russian (US Census Bureau, 2004). In the 1990 census 2.9 million persons declared their ethnicity as 'Russian', while approximately 390,000 persons named the place of their birth as USSR. There is nothing surprising in the reduction of 'Russians' in the USA between the 1990 and 2000 census, because after a certain period of life in the USA many people's start to consider themselves 'American'. According to the immigration estimates of the US Census Bureau, about 460,000 persons born in Russia lived in the USA in 1994, while, by 2003 , this figure went up to approximately 544,000 persons. Thus, over this period, the Russian Diaspora had, in fact, increased on account of direct immigration by about 154,000 persons. The largest contingent of Russians (39\%) lives in the North-East of the USA. Here the largest community is concentrated in New York - about 300,000 persons (Vanichkin: www.rusedina.org). It is understood that since 1991, the Russian community in New York has practically doubled, its rate of growth reaching 190\% (this is high, but still slower than the growth of many other migrant communities (e.g. immigrants from Mexico, Bangladesh, Pakistan etc.). Brighton Beach in Brooklyn is considered to be the district with the most compact settlement of immigrants from Russia. Approximately a quarter of Russians live and work on the West Coast, with the largest communities in San Francisco, Los Angeles and Seattle. Highly-skilled Russian migrants (mainly scientists and IT specialists) are concentrated in the Silicon Valley. Accordingly to the data of the US Census Bureau there are some US towns where the proportion of Russians in the overall size of the population is particularly large. For example, in Peaceful Valley (Washington State) and Concordia (New Jersey) over 22\% of inhabitants declared themselves Russian by origin (Vanichkin: www.rusedina.org). Approximately 19\% of US Russians live in the South (mainly in Miami) and $17 \%$ in the Midwest (mainly in Detroit). According to Russian statistics, between 1994 and 2004 only approximately 14,300 persons went to the USA from Russia with labour contracts. This suggests that approximately only $4 \%$ left to work abroad legally. It is impossible to keep track of the number of Russian labour migrants in the US in any detail based on data published there. However, according to OECD information, approximately 17,000 Russians were admitted to the US in 1997 alone. This suggests that Russian data on labour migration to the USA is a considerable underestimate. Such gross disproportions are confirmed by IOM estimates, according to which about 130,000 highly-skilled Russian specialists are working in USA (IOM, 2002). This, of course, is just a 'drop in the sea' of the overall American labour market, in which in 2003 about 21.6 million persons worked. Russia is by no means a considerable supplier of foreign labour force into the USA, when compared to 6.5 million Mexicans (who occupy the 1st place) or even the 322,000 Colombians (who occupy the 15th place) (OECD, 2005). The majority of Russians working in the US are employed in the computer industry and the service sector. In cases where labour migrants work in their own profession, they are often employed by compatriots who had settled in the US earlier. There are, of course, also plenty of Russian students, trainees or scholars on various exchange programs, who end up working in the US in some form or another, while even some tourists may be added to the number of those who have legally entered the US for purposes of employment. Many of these work illegally, of course, because their visas have expired. Our own estimate of the size of the 'new' section of the Russian Diaspora, which would include those who have migrated in the past 10-15 years, is about 300,000 persons. A large proportion of this new Diaspora stays in regular contact with their Motherland. The 
phenomenon of the flow of Russian immigrants in the US, closely linked to the political, economic and religious aspects of life in both countries, interested in both Russian and American researchers for a long period of time (Nazarov, 2009). Processes of adaptation and assimilation of Russian immigrants, as well as aspects of the relationship between the various waves of emigration remained poorly understood.

The Russian Diaspora in Europe. Russian labour migrants are present in many countries of Western Europe (Ryazanova-Clarke \& Wade, 1999). In London and the South East there are a number of Russian schools aimed at teaching Russian language and culture to children of Russian immigrants (Buksh, 2007). In Germany about 3 million persons consider Russian to be their native language, while as many as 40 million understand or speak at least some Russian (immigrants from NIS-countries or East Germans, who learned Russian at school in Soviet times) (Karabulatova \& Smorodin, 2014). According to a representative sociological survey conducted by the Heidelberg Institute "Sinus Sotsiovizhn" Russian diaspora is the most representative in Germany, it is $21 \%$ of the total number of migrants. Only ranks second Turkish diaspora (19\% of migrants), followed by residents of Southern Europe (Italy, Spain, Portugal, Greece) - 12\%, then the Poles (11\%) and immigrants from the former Yugoslavia (10\%) (Russki mir, 2009). In 1998 there were about 50,000 persons in Germany with former Soviet or NIS-countries citizenship. According to German data, in 2002 approximately 156,000 German citizens were born in Russia. Yet ethnically the Russian Diaspora in Germany is diverse and represented by Germans, Russians, Jews, and representatives of Caucuses peoples (Kudryatz: www.rusedina.org). According to official Russian statistics, only about 25,000 persons (or $7 \%$ of the total flow of labour migrants from Russia) left to work in Germany between 1994 and 2004. According to IOM data, approximately 50,000 Russian experts and IT specialists work in Germany (IOM, 2002). About 75,000-100,000 persons currently living in Germany could be viewed as part of the 'new' Russian Diaspora. the German sociologists point out that, despite the stereotypical image is not too educated native of some Eastern European countries, the Russian-speaking diaspora significantly increases the average level of education of immigrants living in Germany. At the beginning of 1990s in the Russian Diaspora in Great Britain was split between the super rich and the down-and-outs who looked for any work they could get. Many of the former purchased expensive real estate in fashionable London districts, costing several million pounds sterling. Their high investments in the British economy (emblematic of which is Roman Abramovich's purchase of Chelsea football club) are proving to be considerable. Over time, however, the composition of Russian migration to the UK has changed and at present the representative majority belongs to the middle class, who have entered Britain either on temporary jobs or hoping to acquire a permanent residence, while there is also a sizable number of students sent specially to study in British schools and universities. According to the Russian Embassy in the UK data, there are at present about 100,000 ethnic Russians living in London and its suburbs (Nalbaldyan, 2005). According to other estimates, there are about 150,000-200,000 of Russian-speakers in London (www.bbcrussian.com), and these figures tend to include all the Russians/ Russian-speakers from different migrant waves. Russians form only a small proportion of large numbers of labour migrants from Central and Eastern Europe who are coming to work in Great Britain legally or otherwise, with particularly large numbers coming from Poland, while among Russian-speakers there are large numbers of Ukrainians and Lithuanians. According to Russian statistics 25,500 persons (over $7 \%$ of the total flow of labour migrants from Russia) went to Britain for employment between 1994 and 2004, although this is again a substantial underestimate and the total estimate for the 'new' Russian Diaspora is around 100,000. Another example of Russians in Europe would be Finland. In 1994 there were approximately 24,800 persons living in Finland who were born in Russia, while in 2002 this number went up to 36,300. Russians are the most numerous group of foreigners in Finland the number of Russian labour migrants in Finland has been rising steadily: 9,700 in 1995; 20,600 in 2000, 22,700 in 2001, 24,300 in 2002. Russians constitute $90 \%$ of immigrants to the East of Finland and represent a crucial injection of labour in areas around the towns of Lappeenrantra, Imatra and Tokhmayavri, where Russian is heard more and more often and where one finds notice boards in Cyrillic. Currently, increasing economic and cultural impact on the lives of Russian-speaking community in Finland (Prian.ru, 2011). A number of municipalities of Lappeenranta, Imatra and Tohmajärvi put forward a proposal to introduce in their schools the teaching of Russian instead of Swedish. According to Finnish census data there were only about 8,800 Russians of working age living in Finland in 2000. Officially the rate of unemployment among them was considered particularly high (about 48\%) (Statistics Finland, 2003). The number of labour migrants who entered Finland legally from Russia is only 139 persons between 2002 and 2004, according to Russian statistics. The going estimate for the 'new' Russian Diaspora in Finland is below 25,000. A much larger Russian Diaspora has formed in Cyprus. The island attracts Russians in many ways - to rest, settle, place capital investments, or work. Approximately 30,000 immigrants from the former USSR live in Cyprus permanently. Ethnically these include Russians, Ukrainians, Greeks as well as representatives of other ethnic groups. This Diaspora formed over the last ten-fifteen years thanks to close economic, cultural and political links, which had developed already in Soviet times, when Soviet ships were being in Cyprus and when extensive political links were maintained between the Communist Parties of the two states. It is not by 
coincidence that many former Soviet Party officials ended up in Cyprus after the break of the USSR. The Russian Diaspora is concentrated mainly in Limasol town on south-eastern shore of the island, which has been dubbed 'little Russia'. Over time parts of the Russian elite also found it beneficial to settle in Cyprus. In the 1990s rich Russians placed investments, opened businesses, and purchased real estate here, partly thanks to a favorable taxation regime and partly thanks to its convenient geographic location, suitable for conducting business with partners from the Middle East, Southern Europe and North Africa. At present, many of these businessmen live and work a half of their time in Russia and the rest of time in Cyprus, while their families live on the island permanently. About 21,000 Russian companies are officially registered in Cyprus, which brings about 3 billion dollars to the Cypriot economy. Conversely, Cyprus occupies second place in terms of foreign investments into Russian economy, and this is practically all due to the Russian Diaspora investments returning back to the Motherland. Indeed, Russian business migration to Cyprus has been supported by both Russia and Cyprus, in part through a visa-free regime between the two countries. This has also led to the opening of Russian banks, shops, restaurants and schools on the island. About 140,000 Russian tourists come here annually. All of this has increased demand for Russian-speaking personnel as well (jurists, domestic workers, teachers, etc.). According to Russian statistics data about 75,000 persons (one fifth of Russian labour migrants) have gone to work to Cyprus between 1994 and 2004. However, when Cyprus was about to join the EU its migration and taxation policies had to change. From 30 Sep 2003 it abolished the visa-free regime with Russia although some simplified visa procedures are in place for Russians with work-permits who can stay in Cyprus for 90 days. Cyprus also had to stop its offshore investment banking. All of this is likely considerably to reduce the flow of migration and business relations between Russia and Cyprus, although the Cypriot government is doing its best to obey by EU rules, while at the same time keeping the flow of Russian capital through the island as high as possible. Today, the Russian-speaking community of Cyprus has on different data, from 20 to 50thousand people, most of whom live in the cities of Nicosia, Larnaca, Limassol and Paphos. In the latter - the largest Russian-speaking community, about 10 thousand people. Thus today the Russian diaspora in Cyprus has a high degree of institutionalization on the island, there are several large organizations of Russian compatriots out Russian-language magazines, radio and television stations in Russian (Russian Cyprus, 2009). The results of studies that are regularly held in the territory of the EU, showed that about 6 million people, speaking in Russian, permanently reside in European countries. To understand a lot or a little, enough to imagine that about the same number of people living in the territory of Denmark, Finland and Slovakia. That is, together, representatives of the Russian diaspora in Europe could easily create their own autonomous state. Despite this, experts are in no hurry to talk about until the Russification of the West. Today in major European capitals are increasing representatives of the "heel" of the wave of immigration. We are talking about Russian-speaking specialists who arrived in the Old World is not in order to settle here permanently. First of all, they are interested in the prospect of employment, which is why they are not concerned with moving to a permanent residence. They regularly fly charter flights to their homeland and come back (Russian diaspora in Europe, 2015).

The number of temporary migrant workers in recent years has increased significantly, and this is not surprising. The Russian factor is beginning to play a significant role in the global economy, so the young professionals and skilled workers continue to storm the European labor market. This situation could not help but reflect on the state of Russian diaspora in Europe. The new generation of immigrants is not interested in that forge strong cultural ties with their compatriots went abroad. If earlier Russian-language publications and TV channels were the only thread linking migrants with their homeland, now with the advent of the Internet, many problems have decided themselves. To watch a movie in Russian, or get the latest news from home, just visit a particular site. However, a new generation of immigrants faced with another problem: their children in most cases are not able to communicate in their native language with their peers. Part of this issue can be resolved by giving the child in school, in which teaching is conducted in Russian. Enrolling in this educational institution, children have the opportunity to not only learn, but also to communicate with the same age in their native language. However, it should be noted that such schools are not so much

The Russian Diaspora in Asia. Many Russian regions, especially those in the Far East, send labour migrants to the countries of the Asia-Pacific region. More than 6,000 Russian citizens were registered as living and working in Japan in 2002, despite the fact that the Japanese labour market is overcrowded and that it is generally difficult to find work there. The main regions of Russian settlement here are Tokyo (about 1,400 persons), Kanagava (500 persons), Khokaido (500 persons), Niigata (200 persons) and Osaka (200 persons) (Ryazantsev, Horie \& Kumo, 2010). Many Russians work in Japanese seaports, serving Russian ships. Most Russian women are employed in the entertainment industry for which Japan grants special visas. Japan is also very popular among Russian businessmen, who buy here secondhand cars very cheaply for resale in Russia. A particularly large number of cars imported from Japan may be seen in the streets of Vladivostok. About 10,000 persons out of approximately 32,000 Russians who visited Japan in 2002re businessmen. About 16,500 Russians entered Japan legally to work between 1994 and 2002. Russian labour migration to Japan can be 
estimated at around 8-10,000. About 3,000 Russians are working legally in the Republic of Korea. According to Russian statistics approximately 5,000 Russians were living there in 2000. Since that time their number has undoubtedly increased, but neither the Russian Embassy nor the Korean authorities have any precise data. Russians mainly live in the capital Seoul and the port of Pusan. Pusan has a Russian quarter dubbed 'Texas'. These are mainly immigrants from the Primorsky and Khabarovsk regions, who came to Korea for temporary work but ended up staying there for longer. The majority of Russians are employed in low-paid jobs and harmful chemical industries or the entertainment sector. Korean businessmen tend to recruit Russian women for work as waitresses, and many of them work as prostitutes. In 2001 the Russian Embassy in South Korea published data, according to which nearly 5,000 Russian women were employed in bars and brothels. In addition to this Korea depends on foreigners especially in science and technology. Accordingly to a survey of private firms and scientific centers, conducted by Korean Industrial Technologies Association, foreigners work in $10 \%$ of them, with their numbers increasing rapidly. Russian specialists, many of them renowned experts, are the largest contingent of highly-skilled specialists in science and technology employed in Korea and tend to be especially respected there (Kutachov: www.rusedina.org). Recently, South Korean authorities are keen to expand its recruitment of specialists from Russia beyond the chemical industry to include spheres such as nuclear energy and aeronautics. One must also not forget the significant number of Russian Koreans-repatriates left the Russian Far East as part of an official program for the repatriation of Sakhalin Koreans. These ethnic Koreans speak Russian well and tend to gravitate towards Russian districts, where they work in trade or as interpreters. Russian diaspora in China, there is a significant growth in recent years, and as a rule, it is not only come from the border areas with China, but also from Central Russia (Karabulatova \& Zhen Xiumei, 2011). At the same time we see increased migration from China to Russia that requires careful analysis and development of new approaches (Ryazantsev \& Yang Hongmei, 2010). Waves of Russian migration and reach India (Krovvidi, 2014), Australia (Ryazantsev, 2013) and the Middle East (Karabulatova \& Al-Jeyran, 2014).

As regards the Middle East, between 5,000 and 25,000 Russians live and work permanently in the United Arab Emirates (UAE). All attempts by the Russian Consulate there to register compatriots have proved unsuccessful. There are no parts of the country where Russians would live in compact settlements. Enterprising Russians found their place in the trade sector, especially in Dubai. Approximately $80-90 \%$ of Russians have their own business, especially in Dubai. Many are former "chelnoks" who in the early 1990s realized that it was more profitable to act as mediators between Russian businessmen and residents of the UAE than to transport goods to Russia. The trade of fabrics, spare parts, and domestic appliances was especially developed to begin with, but slackened with time. Those Russians who could adapt to the developing needs of the Russian market (for example, by moving to building materials in the period when Russia was experiencing a construction boom) continued to trade very well. Conditions for running a business in UAE have been close to ideal, with hardly any taxes and low customs duties. The downside is that in UAE foreign citizens have very limited rights and often find it difficult to prolong their work visas, or to own land and real estate. Ethnic migration gives rise to the phenomenon of ethnic marginality. At the same time belonging to the Diaspora and participation in it should be interpreted as the result of personal choice, self-organization, and not as a consequence of the initial membership of a particular ethnic group, from which it follows that legislative regulation should cover only the situation of collective manifestations of the diaspora. It is characterized by a conscious and voluntary participation in ethnic communities, associations, other forms of ethnic activity in areas where, etc.

\section{Discussion}

As ethno-political community of the Diaspora are characterized political demands associated primarily with the ethnopolitical self-determination, the right to communication with their historical homeland and related ethnic groups, the creation of social, political associations to protect the rights of members of the diaspora (including internationally) and political participation. Since the Diaspora, as the subject of ethno-political relations, seen in modern ethno mostly in conflict paradigm, its determination is associated mainly with the ethno-political tensions. Meanwhile deserves attention ethno-political conflict-positive experience of diasporas, which consists in their political behavior as integration of subjects and participants consensus ethnic policy. Therefore, the methodological arsenal of well-known authors in this field, as Abdullatipov R., V. Achkasov, S. Babaev, L. Drobizheva, A. Zdravomyselov and others, in the works of many of the ideas that are developed by foreign researchers that have become classics and have a high citation index in conflictological literature (Ritzer G., P. Sorokin, L. Coser, Ralf Dahrendorf, L. Krizberg and others.). Diaspora becomes a form of selfidentity of many groups of old residents of Russia. So, some of the Armenians, Greeks, Koreans, Germans, Poles and other Russian citizens of foreign origin, are united in the national-cultural autonomies and centers, various associations for cultural and ethnic lines. In this regard, it is necessary to study ethno-political factors that contribute to the intensive care unit, "awakening" and mobilize the diaspora ethnicity (Kim, 2009). Being for the recent years as one the contributors 
to academic and political search for a formula for a new Russia, Valery Tishkov advocates the idea that Russian nation building process should be based on the principle of civic nationalism (Tishkov 1997, p. 12). V. Tishkov relies on the constructivist school of thought and draws his thought on modern theories of nationalism. He sees an ethnic group not as naturally determined but as a modern social construction. Being disagreed that nationalism is always present, Tishkov comes to the conclusion that "the major obstacle for Russia to become a "normal" state is not an ethnic mosaic per se but a real "fire in a brain" seeded by elitist social engineers into mentality and language concerning ethnicity and nationality issues (Tishkov, 2015). Tishkov's second suggestion in nation- building process is related to administrative system. Due to the fact that 18 million out of a total 27 million of the non-Russians lives outside ethnic autonomous areas, federalism should not been ethnically based. Rather extra-territorial ethnic and cultural autonomy should be established (Tolz, 2001). In order to win in this geopolitical struggle, Dugin calls Russia to rebuild its empire. He argues that Russia without being empire cannot survive. Russia has an imperial tradition which contradicts the Western style of national state. In Europe, society was transformed from empire to nation-state. In turn, Russia has never been a state in terms of Western perception. Russia's imperial tradition did not bring the borders as European states have. At this point, Dugin argues that because of its imperial mission, Russia should expand its territory through Eurasia (Shlapentokh, 2007).

The imperial Russia will be the center of this bloc which will reach out the seas and oceans in the north, south and the east. The rejection of Atlanticism, US hegemony, values of liberalism and capitalism will be the common policy of this geopolitical bloc including different civilizations (Parland, 2005). In this context, Graham Smith argues that there are three nationalizing projects 159 constructed by nation builders of ex-Soviet republics. At first hand, nationalizing political elites destructed symbols, political institutions and representatives of Soviet power from the political and social sphere. Graham Smith calls this process as deSovietization. Specially, in the case of Baltic states, the policy of de-Sovietization removed the Communist Party from the political scene and radically transformed the main political institutions and symbols of Soviet era. Throughout this period, new national symbols and political institutions which define national interest are established (Smith, 2002). The promotion of a titular language has met serious difficulties in the ex-Soviet republics since Russian speakers compose of not only by ethnic Russians but also those non-titulars who speak Russian. Particularly, attempts to build new nation on the ground of a titular culture and language create threats for the Russian diaspora. These attempts ignore Russian culture and traditions; and exclude Russians' participation to political and social life. For instance, the language policy of Latvia requires all inhabitants to speak Latvian as a condition of becoming citizen.

While Russian settlement was very old in Ukraine, most Russians immigrated in to Latvia and Estonia since World War II. Diaspora Russians are employed in industry and technical professions with higher salary in Central Asia, while blue collar Russian workers dominate the Baltic region. There is significant cultural distance between titular nations and Russian diaspora in Kazakhstan and Kyrgyzstan, while in Ukraine and Belarus, Russians share Slavic identity with the majority. In the northern Kazakhstan, northeastern Estonia, parts of Ukraine which are major areas for concentration of Russian population, Russian diaspora pursues political ambition to establish autonomy and in some cases irredentist claims. On the other hand, the Russians who are dispersed in cities can only strive for cultural autonomy.

\section{Conclusion}

A new Russian Diaspora is forming in unique conditions, which have to do with the consequences of the break-up of the Soviet Union as well as large waves of global economic emigration from Russia ever since. The new Russian Diaspora is made up of people with a variety of migration motivations, including permanent resettlement, labour migration, academic migration, marriage, etc. Nowadays the largest parts of this new Russian Diaspora live in the USA, Germany, Israel, Great Britain and elsewhere. This Russian Diaspora is not ethnically homogenous but includes representatives of various ethnic groups: Russians, Jews, Tatars, Chechens and representatives of many other peoples. They themselves are often referred to simply as 'Russians', although some statistics group them as them as 'migrants from the former USSR', while in certain countries there are special categories, such as the 'Russian Germans' in Germany. The new Russian Diaspora show a propensity for quick and successful adaptation to the host countries, esp. since many of them have a higher than average level of education. This also leads to a quick assimilation, at least in some countries, such as the USA, where many migrants start to consider themselves Americans. On the whole this new Diaspora shows little inclination for consolidation in specific areas of compact settlement as used to be the case in some of the earlier émigré waves (although there are some partial exceptions). There is however a growing number of nongovernmental Diaspora organizations that bring this Diaspora together according to various social, cultural and economic interests, providing support in helping new migrants adapt to their host country. The new Russian Diaspora performs important social and economic functions ensuring global collaboration in spheres of business, trade, science, culture, education, and social support. Diaspora is particularly important in advertising Russian culture and the Russian language in their host countries. 
In many countries it provides support in realms such as sport, art, science and education. All of this impacts on the formation of a positive image of Russia abroad. The Russian Diaspora also shows great potential for collaboration with Russia itself, which is why Russian state policy towards its Diaspora has great importance. For a long time official state policy towards compatriots of both the USSR and Russia has been practically absence, and sometimes sought deliberately to isolate itself from it. It was only in 1994 that the State Commission on Compatriots' Issues was established and in 1999 that the Federal Law of the Russian Federation towards Compatriots was passed. In 2006 the State Program for the Support of Voluntary Migration of Compatriots to the Russian Federation was passed. There is now a special Committee on Compatriots' Issues in the State Duma. There are also several mechanisms for supporting compatriots on the regional level. For example, the Moscow Government awards special scholarships to compatriot students from the $\mathrm{CIS}$ and the Baltic States who wish to studying in Moscow universities. At this point, it is worthy to focus on the explanations of Lowell Barrington, Erik S. Herron, and Brian D. Silver in order to analyze Russian diaspora' perceptions of homeland in details. In contrast to Zevelev's conclusion that all Russians in newly independent post-Soviet states see Russian Federation as their external homeland, they identify possible homelands' perceptions of Russians living out of Russian boundaries. They argue that an individual or group could have several possible homelands: External homeland, internal homeland and mixed (external-internal homeland). In the case of external homeland, a minority does not perceive its state of residence as its homeland. In fact, the group views a region which is out of the boundaries of its country of residence or state as its true homeland. While in some cases, the perception of external homeland could engender secessionist claims; it, generally, could lead the government of the external homeland to act on behalf of the minority groups. If there is a basis for claim of discrimination towards the minority, the external homeland may apply the diplomatic, economic, military pressure on the states where its minority settles. The internal homeland refers to a part of the state of residence. In such a situation, the minority views a region as its national homeland and demands political control over that territory. The territory is, also, thought as the national homeland of the majority. This perception of the homeland emerges in a state that includes a sizeable and concentrated ethnic minority. Hence, the thought of internal homeland could fuel secessionist drives and causes ethnic conflicts within the state of residence. However, further work needs to be done on strengthening state measures for assisting in Diaspora consolidation and supporting its collaboration with Russia in a whole variety of spheres, especially business, cultural and educational. Many other countries in the worlds are developing similar policies towards their Diasporas and their experience ought to be useful for Russia too.

The article prepared within the RFBR grant, № 15-06-02854, "Economic-mathematical modeling of social reserves Russia's demographic development: a systems approach".

\section{References}

Abdullatipov, R.G. 2005. Russian nation (ethnic social and civil identity of Russians modern conditions. Moscow. pp. 25.

Achkasov, V.A \& Babaev S.A. 2000. "Mobilized ethnicity": ethnic dimension of political culture in modern Russia. St. Petersburg: Publishing House of the St. Petersburg Philosophical Society. pp. 145.

Akaha, T. \& Vassilieva A. 2002. The Russian presence in Japan:Case studies in Hokkaido and Nigata, Human flows across national borders in Northeast Asia: Seminar Proceedings, United Nations University, Tokio, pp. 113-125.

Buksh, A. 2007. Russians get back to their roots.

Curto, O.I. 2010. Heritage dynamics and current situation of the Russian diaspora in China. 2010, electronic resource.

Dahrendorf, R. 1990. The Modern Social Conflict: An Essay on the Politics of Liberty. -Berkeley: University of California Press. pp. 219.

Değirmen, F.B. 2008. Russian Diaspora and the Politics of Russian Nationalism in the post-Soviet era. Middle East Technical University. p. 110.

Drobizheva, L.M. 2002. Russian and ethnic identity: confrontation or compatibility. In the: Russian reformed. Edited by L.M. Drobizheva. Moscow: Academia. pp. 213-244.

Karabulatova, I.S. \& Karelina L.F. 2006. Ukrainian Diaspora of the Tyumen region: history, language and culture. Tyumen: Pechatnik. pp. 180.

Karabulatova, I.S., Zhen Xiumei. 2011. The peculiarity of modern Russian migration channels in China. In the: Migration bridge between Central Asia and Russia: The role of migration in the modernization and innovative development of the economy of the sending and receiving countries. Proceedings of the International Symposium 3. Moscow: Publishing House "Eco-Inform". pp. 263-268.

Karabulatova, I.S. 2013. The problems of linguistic modeling of new Eurasian linguistic personality in multilinguistic and mental environment (by example of onomasphere). In the: Middle-East Journal of Scientific Research 17 (6). pp. 791-795.

Karabulatova, I.S., Sayfulina F.S. \& Ahmetova B.Z. 2013. Ethno-lingual aspect of modern functioning of Russian dialects in North Kazakhstan (on an example of Kostanai region) // World Applied Sciences Journal Issue 27 (Education, law, economics, language and communication). pp. 137-140.

Karabulatova, I.S. \& Smorodin E.B. 2014. Overall sociolinguistic characteristics of personal transformation in modern labor migrant in Germany in the context of international migration. In the: Migration bridges of Eurasia: Proceedings of the $\mathrm{VI}$ International 
scientific-practical conference "The role of migration in the socio-economic and demographic development of the sending and receiving countries of Eurasia." Ed. Corresponding Member of RAS, Dr. ekon.n. Professor S.V.Ryazantsev. M.: Publishing House "Eco-Inform", 2014, pp.: 193-197.

Karabulatova, I.S. \& O.Al-Jeyran 2014. Ethno-Linguistic- Propaedeutics of conflicts in the information sphere in a situation of migration: Russia and Bahrain. In the: Migration bridges of Eurasia: Proceedings of the VI International scientific-practical conference "The role of migration in the socio-economic and demographic development of the sending and receiving countries of Eurasia." Ed. Corresponding Member of RAS, Dr. ekon.n. Professor S.V.Ryazantsev. M .: Publishing House "Eco-Inform". pp. 54-60.

Kim, A.S. 2009. Ethno-political study of modern diasporas. St. Petersburg, Saint Petersburg State University. pp. 41.

Krisberg, L. 1973. Sociology of Social Conflict. New Jersey: Prentice-Hall. pp. 324.

Krovvidi, E. 2014. Russians and Buharis: Bound by similar mentality.

Kudryatz, E. Russian-speaking Germany, www.rusedina.org, (date of base 30.01.2015).

Kutachov, V. Is Korean science Russian? www.rusedina.org, (date of base 31.01.2015).

Lee, J.H. 2002. A Review of Data on Trafficking in the Republic of Korea, IOM, Geneva.

Levin, Z.I. 2001. Mentality of Diaspora (system and socio-cultural analysis). Moscow, Institute of Oriental Studies RAS, Kraft +. pp. 172.

Lowell, W. Barrington, Erik S. Herron, \& Brian D. Silver 2003. The Motherland Is Calling: Views of Homeland among Russians in the Near Abroad. World Politics, Vol. 55. pp. 293.

Nabaldyan, Z. 2005. If he had brought patrons?, Labour (136).

Nazarov, P.V. 2009. Russian immigrants in the United States in the late XIX - early XX century. Dissertation of the candidate of historical sciences, Surgut. pp. 218.

Nitoburg, E.L. 2001. At the root of the Russian Diaspora in America . In the: USA. Canada: Economics, Politics, Culture. T.\#9. pp. $79-97$.

Nitoburg, E.L. 2003. The fate of Russian immigrants of the second wave in America In the: History of Russia. T.\#2, pp. 102-114.

Parland, Th. 2005. The Extreme Nationalist Threat in Russia: The Growing Influence of Western Rightist Ideas, New York: Routledge Curzon. pp. 128-129.

Popkov, V.D. 2003. Diasporic community in intercultural interaction: the way of formation and development trends: Author. dis. ... Doctor. soc. Sciences. Moscow.

Pronin, A.A. 2001. Russian emigration in modern historiography. In the: International historical journal. \# 16.

Prian ru. 2011. Russian language could displace the second state in the schools in Finland.

Rowley, David G. 2000. Imperial Versus National Discourse: The Case of Russia, Nations and Nationalism, Vol. 6, No. 1. pp. $23-32$.

Russki mir. Russian Diaspora in Germany - the most educated and numerous, 2009.

Russian Cyprus, 2009. Electronic resource. http://russkiymir.ru/publications/85356/.

Russian diaspora in Europe, 2015. Electronic resource. http://evropoi.ru/diaspora-v-evrope/.

Ryazanova-Clarke L., Terence Wade 1999. The Russian Language today. London, Routledge. pp. 384.

Ryazantsev, S.V. \& Yang Hongmei. 2010. Chinese migration in Russia: trends, consequences and approaches to regulation. Moscow: Publishing House "Eco-Inform". pp. 147.

Ryazantsev, S.V. 2013. Migration from Russia to Australia and formation of a Russian Community. In the: Anu College of Arts \& Social Sciences, Vol.4, No 5.

Ryazantsev, S.V., Manshin R.V. \& Khanh Toan Nguyen 2013. Comparative Analysis of Vietnamese and Chinese Migration to Russia. In the: Migration Law, Issue 1. pp. 21-42.

Ryazantsev, S.V., Norio Horie \& Kazuhiro Kumo 2010. Migrant Workers from Central Asia into the Russian Federation. Tokio, Institute of Economic Research, Hitotsubashi University. pp. 33.

Ryazantsev, S.V. \& Bozhenko V.V. 2014. New approaches to Managing labour migration under integration in Eurasec. In the: Asian Social Science. Vol. 10, \#20, p. 1-7.

Riazantsev, S.V., Pismennaya E.E., Karabulatova I.S. \& Charif Y.Akramov 2014. Transformation of sexual and matrimonial behavior of Tajik labor migrants in Russia. In the: Asian Social Science. Vol 10, No.20.

George, Ritzer. 2007. Modern Sociological Theory (7th ed.). New York: McGraw-Hill. ISBN 0073404101, pp. 357.

Sensus, U.S. 2000. Language Use and English-Speaking Abillity.

Statistical Finland, 2003 Population Census 2000, Helsinki.

Sorokin, P.A. The socio-cultural dynamics and evolutionism.

Shlapentokh, D. 2007. Dugin Eurasianism: A Window on the Minds of the Russian Elite or an Intellectual Ploy. In the: Study East European Thought, Vol. 59. pp. 230.

Smith, G. 2002. The Post Soviet States: Mapping the Politics of Transition, London: Arnold. pp. 272.

Valery, Tishkov 1997. Ethnicity, Nationalism and Conflict in and after the Soviet Union: The Mind Aflame, London: SAGE, 1997, p.12.

Valery, Tishkov. What is Russia? Perspectives for Nation-Building.

Vera, Tolz 2001. Russia, New York: Oxford University Press. pp. 249-250.

Vanichkin, P. Over 2,6 million of Americans consider themselves to be Russians.

Zdravomyselov, B.V. 1991. Classification of bribery. Moscow, pp: 72. 
ISSN 2039-2117 (online) ISSN 2039-9340 (print)
Mediterranean Journal of Social Sciences MCSER Publishing, Rome-Italy
Vol 6 No 3 S4 May 2015 